\title{
DETERMINING FACTORS PROMOTING DESIGN OF MUSIC CENTERS IN NATIONAL URBAN SPACES (STATISTICAL POPULATION: CITIZENS OF SARI- PROVINCIAL CAPITAL OF MAZANDARAN, IRAN)
}

\author{
Somayeh Zakiyan Galogahi \\ MSc in Architecture Engineering, Instructor of Sama Technical and Vocational College, Islamic Azad \\ University, Sari Branch, Sari, Iran \\ s_zakiann@yahoo.com \\ Majid Alishah \\ Graduate Student, Department of Architecture, Azad University of Sari \\ Rohallah Amoo Zadeh \\ Graduate Student, Department of Architecture, Azad University of Sari \\ Sayed Rasool Rassoli \\ Graduate Student, Department of Architecture, Azad University of Sari
}

\begin{abstract}
Music is a clear reflection of people's life and culture in a country that due to its capacities can contribute to introduction and transference of the nation's culture. Applying descriptive-analytical method and with the aim of identifying determining factors promoting the design of music centers in national urban spaces, this paper was prepared. In the current research, people living in Sariprovincial capital of Mazandaran, Iran- were chosen as statistical population. According to Morgan's table, this population equals 389 samples (involving $48.3 \%$ men and $51.7 \%$ women). The collected data was tested applying SPSS and the results indicated that in music center spaces, qualitative factors are of higher importance than individual and social factors. Here is a hierarchic list of items respondents referred to in their responses: Aesthetics in the form of buildings by combination of architecture and music in the building; Proving people with psychological security in populous areas such as music centers; creating dynamism and attraction by good lighting and music at night; including inexpensive spaces for music practice in music centers; Inviting great music teachers and masters to make music centers more successful, and using happy and energetic colors in the design of music centers. These items emphasize the importance of considering the design of optimum music centers in country.
\end{abstract}

Keywords: music, public spaces, music center, urban spaces

\section{INTRODUCTION}

Music is one of the oldest human arts that was formed in the primitive culture and then has evolved through the time. Compared to other forms of art, music, which is supposed to be the simplest and the easiest way for transferring human feelings and emotions, has been more successful in gaining human's attention (Rezaie Nia, 2003:107) and it is considered as the cultural background of every nation. However, in some countries it may contradict religious values and ideals. In today modern world, given the big money spent on culture building and preserving vernacular culture and its introduction to other societies, music as a determining factor and as a symbol representing feelings, thoughts, and spirits can play an important role in creating balance and calming people's spirits (Aqa Ahmadi et al, 2013, 11-13). 
Today, with information and communication technology advancement, the interest in music has had a growing trend and has become an inevitable part of everyday life (Denora, 2004). Due to the large population of young people in communities who are considered the main consumers of music (ReK. Hadynkson and Dixie, 2007) attention to the tastes, trends and needs of this population is essential (Qasemi and Mir Akuri 2012:62). Young people tend to consume music and are committed to it, however due to the fact that in the last two centuries with the growing urbanization (Azizi and Malek Mohammad Nejadi, 2007) which has caused crises in their lives, and therefore has caused them to be far away from each other (Eini Far, 2000 ), and this in turn has contributed to a destruction of the social relations and ignoring of the collective culture in the society, it seems necessary to establish public places like music centers so as to promote music culture in the communities of today world. Places where music is heard by the youth and is considered as a cultural source in the society. In such cultural spaces, music generators and young consumers both are aware of their feelings and try to build the social world where they uncover their identities (Bennett, 2000) to transfer a sense of tranquility to the society. This research aims to determine whether or not music centers can help create spaces that are open to people of different folks and also help create spaces that make idea exchange possible and form sociocultural networks (Hajer \& Reijndropp, 2011). Thus, such interactions and experiences among different people and groups lead to receiving collective identity, self-respect, improving social skills and collaborative partnerships (Douglas, 2003). However, given the lack of scientific studies and research conducted in this field in the author's country, this research is to develop appropriate strategies by identifying determining factors in improvement of music centers.

\section{STATEMENT OF THE PROBLEM}

Music has always been one of the greatest companion of and the closest form of art to man and throughout the history, from rituals to concerts and plays associated has been with him (MahdaviNezhad, 2004:88). Music is a meaningful creative act that has a lot of power in transferring ideas from one mind to another (Iman et al. 2010:87). Given the development and diversity and also the Institutionalization of most needs and their satisfaction in the modern societies, few people can be found who are not interested in this kind of music and evade from consuming such cultural goods (Aqa Ahmadi et al. 2013:10). We; unconsciously, consume music and sometimes we sing along with it, so that this public tendency directs the youth of the country to music and it should be noted that music consumption is an important form of youth leisure spending (Qasemi and Samim, 2009). Rather than a means of enjoying leisure time activity, Music; however, is a means for forming individual feelings and identities. In fact, through the music people and groups consume, they reflect their distinction, identity, class, race etc. (Aqa Ahmadi et al 2013). Without doubt one of the artistic elements that can be used to evaluate the culture of a nation and gain a lot of information on its customs and beliefs is the music of that nation. Music can also be a source for satisfying people's and different social classes needs. Indeed, we can scarcely find ceremonies without music and we can dare to say that it is clearly seen in all get-together, from political and athletic ceremonies to parties or even in the privacy of individuals ( Qasemi and MirAkori, 2012:62). In this country, no weeding is held without music, and pilgrims are welcomed by music, also it is clear that Muharram and its related ceremonies cannot be considered without music. However, given the cultural and religious constraints of the author's country, the essence of live music and music centers should be in such a way that does not conflict with cultural standards of the society. In this research we are to study appropriate solutions with the help of respondents and we will attempt to answer the following questions:

- To what extent are social and demographic characteristics of citizens effective in the design of a music center?

- To what extent are qualitative properties of space and aesthetics important in the design of music center?

- Do individual and the qualitative factors have the same role in the design of a music center? 


\section{LITERATURE REVIEW}

Table 1. A summary of studies conducted regarding determining factors leading to a better design of music centers.

\begin{tabular}{|c|c|c|c|}
\hline & researcher & Subject & Results \\
\hline 1 & Satari et al (2012) & $\begin{array}{l}\text { A study of } \\
\text { similarities } \\
\text { between } \\
\text { Iranian music } \\
\text { concepts and } \\
\text { architecture of } \\
\text { Iranian } \\
\text { gardens (case } \\
\text { study: Kashan } \\
\text { Fin Garden) }\end{array}$ & $\begin{array}{l}\text { They argued that Architecture and music, as } \\
\text { two aspects of the art, have similar effects. } \\
\text { Although music is felt by the phenomenon of } \\
\text { hearing and architecture by vision, both arts } \\
\text { have a lot in common that are explained in } \\
\text { this research. }\end{array}$ \\
\hline 2 & $\begin{array}{c}\text { Sohangir and } \\
\text { Borazjani (2012) }\end{array}$ & $\begin{array}{c}\text { A } \\
\text { Comparative } \\
\text { Study of the } \\
\text { conceptual } \\
\text { link between } \\
\text { music space } \\
\text { and } \\
\text { architecture } \\
\end{array}$ & $\begin{array}{l}\text { In this study, the relationship of space concept } \\
\text { in music and architecture in two periods of } \\
\text { time and the conceptual links between these } \\
\text { two have been investigated }\end{array}$ \\
\hline 3 & $\begin{array}{l}\text { Vadamir et al } \\
\text { (2011) }\end{array}$ & $\begin{array}{l}\text { Youth and pop } \\
\text { (A study of } \\
\text { sociocultural } \\
\text { factors related } \\
\text { with the } \\
\text { Tarbiat } \\
\text { Moalem } \\
\text { students' } \\
\text { orientation } \\
\text { toward Pop }\end{array}$ & $\begin{array}{l}\text { He suggested that music and its evolution and } \\
\text { concepts don't happen in sociocultural vacuity } \\
\text { but it is a sociocultural product. }\end{array}$ \\
\hline 4 & $\begin{array}{l}\text { Qasemi et al } \\
(2008)\end{array}$ & $\begin{array}{l}\text { A study on the } \\
\text { relationship } \\
\text { between social } \\
\text { stratification } \\
\text { and cultural } \\
\text { consumption } \\
\text { using data on } \\
\text { the use of } \\
\text { music in } \\
\text { Tehran }\end{array}$ & $\begin{array}{l}\text { It is argued that the higher the status of } \\
\text { people, the higher their tendency to consume } \\
\text { a variety of music belonging to the elite } \\
\text { culture and the lower their tendency to } \\
\text { consume the music of mass culture. In } \\
\text { comparison with class differences (differences } \\
\text { in economic status) people's different } \\
\text { educational level can better predict the type } \\
\text { and amount of culturally consumed music in } \\
\text { individuals. }\end{array}$ \\
\hline 5 & Atarbak (2008) & $\begin{array}{l}\text { Islamic } \\
\text { reaction to the } \\
\text { music of today }\end{array}$ & $\begin{array}{l}\text { An analysis of the new music of the Arab } \\
\text { world and a focus on what they control in } \\
\text { order to limit music phrases and the function } \\
\text { of religious actors }\end{array}$ \\
\hline 6 & $\begin{array}{l}\text { Barondragett } \\
(2006)\end{array}$ & $\begin{array}{c}\text { Music in } \\
\text { Southeast Asia } \\
\text { and the fear of } \\
\text { Muslim female } \\
\text { voice }\end{array}$ & $\begin{array}{l}\text { It has been stated that in terms of religion, art } \\
\text { of incitation in traditional performances or } \\
\text { popular music is an immoral behavior. Music } \\
\text { and dancing in the Muslim world, especially } \\
\text { fear of the power of sensuous, has been } \\
\text { passionately debated in religious treatises }\end{array}$ \\
\hline
\end{tabular}




\begin{tabular}{|c|c|c|l}
\hline 7 & Xenakis (2008) & $\begin{array}{c}\text { Music and } \\
\text { architecture }\end{array}$ & $\begin{array}{l}\text { He emphasized the role of geometry in } \\
\text { compliance and proximity and studied } \\
\text { examples of music that have become } \\
\text { architecture in his and other architects' works. } \\
\text { He also argued that the relationship between } \\
\text { music and architecture is a virtual and mental } \\
\text { and not a real relationship }\end{array}$ \\
\hline 8 & Davis (2001) & $\begin{array}{c}\text { Music of } \\
\text { works and } \\
\text { Performances }\end{array}$ & $\begin{array}{l}\text { He raised interesting questions about the } \\
\text { nature of musical works, and linked its } \\
\text { authenticity to performance, traditional music, } \\
\text { and records. }\end{array}$ \\
\hline 9 & Bennett (2000) & $\begin{array}{c}\text { Popular music } \\
\text { and youth } \\
\text { culture: music, } \\
\text { identity and } \\
\text { place }\end{array}$ & $\begin{array}{l}\text { He argued that music is produced and its } \\
\text { consumers are youths and both the producer } \\
\text { and consumer are aware of their feelings and } \\
\text { help create a social world where they can } \\
\text { employ their identities. }\end{array}$ \\
& & \\
\hline
\end{tabular}

Source (Author, 2016)

\section{THEORETICAL FOUNDATIONS}

\section{Music}

Without a doubt the most magnificent symphony of creation is nature. God's nature is full of music. Flowers and grass dancing in the wind breeze, the sound of waves on the beach, the song of rivers flowing and sounds of waterfall, birds singing in the garden all are a great symphony of the nature of the masterpiece of creation (RezairNia, 2003,107). Music is an emotional reaction that occurs in the experience particularly the strong ones. How is music influencing us? It can be said that music is one of the most effective emotional experiences in people (Gabrielsson, 2001, 487) and in different cultures, it visualizes different ways of imagining the sounds as music. Therefore, each culture creates its own distinctive patterns out of the difference between image and experience that reflects theoretical thought over music (Cook, 1990. 265). Music formation dates back to the time when man expressed his aspirations, sorrows and joys.

\section{Music in Iranian culture}

In Iranian culture, music has had a deep bond with vernacular culture and religious and spiritual affiliations of the Iranians over the years. A bond which is not weaker, if not stronger, than the link between other forms of Iranian arts with Islamic culture. Islamic philosophy and mysticism can affect the music efflorescence in two ways. The first is that Islamic values provides accurate and efficient way for training music by creating human and spiritual relationship between master and pupil. And the second is that theosophical lessons can create a strong and effective link between masters and public audiences by directing music to spiritual field (MehdiNezhad,2004,88). In traditional culture, mysticism and music have always been alongside taste and Sama (Sufism) and mystical passion (Motahari Elhami, 2003,96) in a way in which words, moving images and dance work together (Cook, 2000 and its manifestation in Sama which is known as a particular liturgy, consisting of prayers, litanies, singing, music and sometimes dance and integrating music into the practice of meditation is an important aspect of contemplative life in Islamic mysticism (Lewisohn, 1997). In addition, Molana repeatedly introduced music as a means of communication with the supernatural world in Shams and Masnavi-e- Manavi and referred to it as the best way of stimulating divine thoughts and escaping from material desires that was used in dance and Sama and was fully a ritual tool (MehdiNejad, 2004, 89). In fact it can be said that music is somehow derived from religion. Music at the outset seems to have a religious aspect and is an expression of beliefs, desires and moods and the means to satisfy inner needs by which sorrow, joy and prayers can be shown (Rezaie Nia, 2003). 


\section{Music link with society}

The fact that music is an emotional reaction that occurs in experiences specifically the strong ones shows how music influences us. Therefore, it can be argued that music is one of the most effective emotional experiences in people (Gabrilson, 2001, 487). Now in response to what music is for, how it works and who can teach us it, we can say that human romantic feelings for evaluation of music is not mere entertainment, but as something fundamental to our experience of listening and communicating in sound and art that has a profound influence on society (McQueen, 1990). The role of our emotion in music composition, the ways in which emotions can be linked through the music is the use of music to express feelings in cinema, theater and music that directs and influences our emotions (Jaslin, Seloboda, 2001, 487). However, music in today world is an important experience. Music, in fact is the successor to tone over time (Stur, 1992), and due to its harmonious, balanced and proportional sounds, which has a natural link with the human spirit, caused human to be attracted to balanced body movement and enjoy the harmonious sound of water flowing in streams and falling from waterfalls and also feel a sense of joy by listening to rhythmic songs (Motahari Elhami, 2003,98). Music is food of soul, and no society can imagine itself without this intellectual product.

\section{Consumers' view on music}

Music is a part of human artistic activity and perhaps it has received more attention than any other artistic production. Today we can hardly find a place where music is not present; it is everywhere in party, mourning, restaurant, subway station, elevator, taxi, waiting room, TV commercial, Cinema etc. Music is flowing in everyday life and we inevitably consume it in all different places, however it's never heard clearly, and even sometimes we hum it unconsciously; and simply our life is integrated with music (Fazeli, 2005, 28). Although most adolescents and young people are interested in music and actually listen to the music as a part of their daily routines, music being played from the local media, has been less based on their demands and this can be a reason why they try to satisfy their needs in this field from different channels (Toosi and Yahak, 2014, 8). In other words, keeping in mind their tastes and preferences in music, we can realize their social status in society (Bryson, 1997, 114).

\section{Public places in urban areas}

Today, with the rapid growth of urban populations, people have always been looking for ways to reduce the negative effects on health of their individual and social life. Among the most important factors that can play a key role in reducing these effects, are public and communal spaces (Kashefi et al, 2012, 7). In these spaces, people presence and their active role in communal spaces come from a sense of place and place itself, due to limitation it puts on social relations in a specified realm, creates and strengthens the sense of belonging to the group, and therefore improves face to face relations (Sarmast and Motavaseli, 2010) and plays an important role in creating a sense of community (Huang, 2006). Moreover, it can be considered as a place where people gathering can enliven urban spaces (Rafiean and Khodaie, 2004).

\section{RESEARCH METHODOLOGY}

According to the nature, subject and objective predicted for this research, we could say it is a descriptive-analytical research and can be categorized as applied research studies. Since questionnaire and interview were used for collecting required data, this research can be survey research. Required data were collected through both libraries and surveys. Statistical population in this research is all citizens living in Sari- provincial capital city of Mazandaran. Applying Morgan table, 389 cases were selected by systematic random sampling and then were directly questioned. Using data collected under SPSS, Kolmogorov Smirnov test (Non-parametric binomial), Binominal Test and Pearson correlation, the relationship between variables were tested.

\section{HYPOTHESIS AND DISCUSSION}

Results are the most important part of research that lead to the development of hypotheses and add new information to past knowledge with the help of research theories (Hafeznia, 2009).

\section{Table 2 qualitative characteristics of the research samples}




\begin{tabular}{|c|c|c|c|c|c|c|c|}
\hline \multicolumn{2}{|r|}{ variable } & \multirow{2}{*}{$\begin{array}{c}\text { frequency } \\
51.7\end{array}$} & \multirow{2}{*}{$\begin{array}{c}\text { percentage } \\
201\end{array}$} & \multicolumn{2}{|c|}{ variable } & \multirow{2}{*}{$\begin{array}{c}\text { frequenc } \\
\text { y }\end{array}$} & \multirow{2}{*}{$\begin{array}{c}\text { percentage } \\
7.5\end{array}$} \\
\hline sex & female & & & \multirow{6}{*}{ 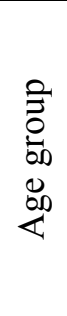 } & Below 20 & & \\
\hline & male & 48.3 & 188 & & $21-30$ & 180 & 46.3 \\
\hline \multirow{5}{*}{ 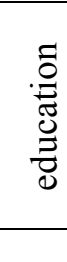 } & diploma & 128 & 32.9 & & $31-40$ & 125 & 32.1 \\
\hline & associate degree & 87 & 22.4 & & $41-50$ & 55 & 14.1 \\
\hline & $\begin{array}{c}\text { Bachelor's } \\
\text { degree }\end{array}$ & 118 & 30.3 & & & & \\
\hline & Master's degree & 45 & 11.6 & & & & \\
\hline & $\mathrm{PhD}$ & 11 & 2.8 & & total & 380 & 100 \\
\hline
\end{tabular}

Source: author (2016)
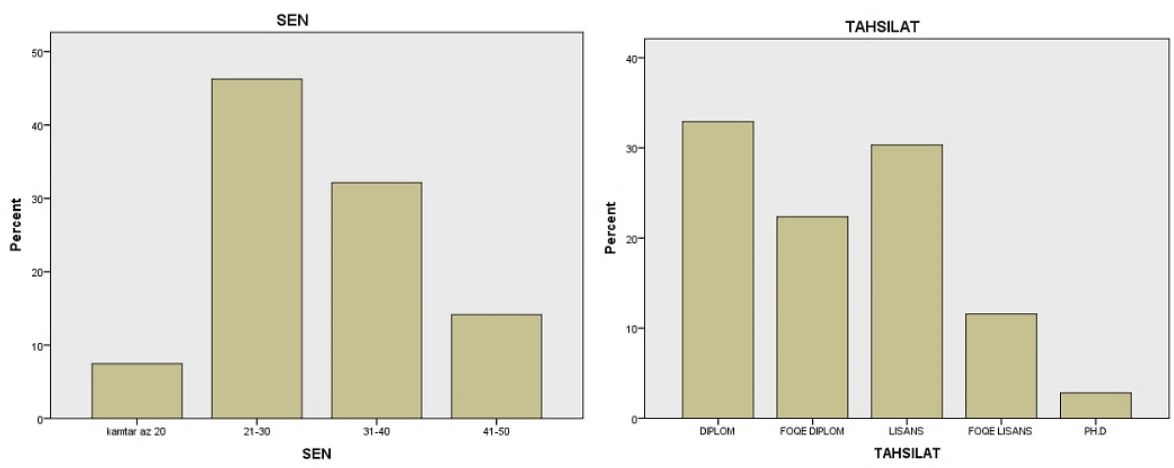

Fig1. The charts of respondents' age and education

\section{The normality of data distribution (Kolmogorov-Smirnov test)}

Most statistical tests including parametric tests are based upon the normality of data distribution and they are applied with this presumption that data distribution in a community or in samples selected from the community follows a normal distribution. Thus, before conducting any statistical analyses on variables, analyzers need to know variables type of distribution. Applying Kolmogorov-Smirnov test, we can achieve this objective. In Kolmogorov-Smirnov test, null hypothesis is that data follow a normal distribution; on the other hand, the alternative hypothesis is that data don't follow a normal distribution. According to the table presented below, as it can be seen in this test, the probability level and $\mathrm{P}$ value is more than error level in all variables $(0.05)$. Given the $\mathrm{P}$ value, Null hypothesis is not rejected and so data distribution is considered to follow a normal distribution. Consequently, nonparametric tests have been used for testing research hypotheses.

Table 3 Kolmogorov-Smirnov test results for evaluating the normal data distribution

\begin{tabular}{|c|c|c|c|c|}
\hline variable & number & $\begin{array}{c}\text { Standard } \\
\text { deviation }\end{array}$ & $\begin{array}{c}\text { Z (Kolmogorov- } \\
\text { Smirnov) }\end{array}$ & P \\
\hline $\begin{array}{c}\text { Factors affecting } \\
\text { promotion of } \\
\text { quality }\end{array}$ & 36.3 & 2.65 & 0.644 & 0.632 \\
\hline
\end{tabular}

Source: author (2016)

Kolmogorov-Smirnov test is not significant for factors affecting promotion of quality $(\mathrm{p}=0.632$ ). Thus it can be concluded that above variables enjoy normal distribution and so we can apply parametric analysis.

\section{The reliability of measurement tools}


Reliability is a tool that is repeatable and can be used for measuring the similar outcomes. In this regard, reliability can be estimated through different methods among which, Cronbach alpha is the very popular in controlling questionnaires reliability (Hafeznia, 2008, 155).

Table 4 The questionnaire individual and social factors reliability

\begin{tabular}{|c|c|c|}
\hline Row & $\begin{array}{c}\text { Individual and social factors affecting the extent to which } \\
\text { people welcome the space }\end{array}$ & $\begin{array}{c}\text { Cronbach } \\
\text { alpha }\end{array}$ \\
\hline 1 & $\begin{array}{c}\text { The effect of users' individual characteristics (age, } \\
\text { education level, gender etc) }\end{array}$ & 1.19 \\
\hline 2 & $\begin{array}{c}\text { The effect of economic status (people's income level) on } \\
\text { the extent to which students welcome music and people } \\
\text { attend concerts }\end{array}$ & 1.04 \\
\hline 3 & $\begin{array}{c}\text { Users' sociocultural conditions (the effect of religious and } \\
\text { popular beliefs... }\end{array}$ & 1.03 \\
\hline 4 & $\begin{array}{c}\text { Satisfying citizens' spiritual needs and providing their } \\
\text { psychological comfort ( especially youths) when attending } \\
\text { concerts and music centers }\end{array}$ & 1.05 \\
\hline 5 & $\begin{array}{c}\text { The effect of the sense of peace experienced by people } \\
\text { listening to music in their leisure time. }\end{array}$ & 1.01 \\
\hline 6 & $\begin{array}{c}\text { The effect of religious constraints on playing and listening } \\
\text { to music or performing a concert ( music from and } \\
\text { ideological viewpoint) }\end{array}$ & 1.08 \\
\hline 7 & $\begin{array}{c}\text { Evaluation of people's tendency (especially youths) to } \\
\text { attend concerts }\end{array}$ & 1.01 \\
\hline
\end{tabular}

Source: author (2016)

Table 5 The questionnaire qualitative factors reliability

\begin{tabular}{|c|c|c|}
\hline Row & factors affecting the extent to which people welcome the & $\begin{array}{c}\text { Chronbach } \\
\text { alpha }\end{array}$ \\
\hline 1 & $\begin{array}{c}\text { The effect of colors used in the design of music centers ( } \\
\text { inside and outside the building such as using happy and } \\
\text { energetic colors }\end{array}$ & 1.03 \\
\hline 2 & $\begin{array}{c}\text { Adding dynamism and attraction to the space by good } \\
\text { lighting and music at night in order to attract more visitors }\end{array}$ & 1.02 \\
\hline 3 & $\begin{array}{c}\text { Creating visual attractions and appropriate viwes such as } \\
\text { green space and fountain as well as playground for children }\end{array}$ & 1.17 \\
\hline 4 & $\begin{array}{c}\text { Availability of outdoor spaces for holding concerts } \\
\text {,ceremonies (harvest), traditional dancing, religious } \\
\text { ceremonies (Tazieh -Passion Play) and street performances }\end{array}$ & 1.19 \\
\hline 5 & $\begin{array}{c}\text { Availability of commercial spaces (selling music-related } \\
\text { stuff such as poster, CD and different instruments etc.). }\end{array}$ & 1.09 \\
\hline 6 & $\begin{array}{c}\text { Providing people's psychological security in such populous } \\
\text { spaces as music centers. }\end{array}$ & 1.14 \\
\hline 7 & $\begin{array}{c}\text { Adding variety to the space by running coffee shops , } \\
\text { restaurants and communal spaces for having interaction in } \\
\text { order to attract all groups. }\end{array}$ & 1.15 \\
\hline 8 & $\begin{array}{c}\text { Separating children's pace from adults' along with keeping } \\
\text { relationship in music centers }\end{array}$ & 1.13 \\
\hline 9 & $\begin{array}{c}\text { Inviting great music teachers and masters to make music } \\
\text { centers more successful ( to perform music, give lecture } \\
\text { and teach etc.) }\end{array}$ & 1.16 \\
\hline 10 & Including inexpensive spaces for music practice in music & 1.08 \\
\hline
\end{tabular}




\begin{tabular}{|c|c|c|}
\hline & centers & \\
\hline 11 & $\begin{array}{c}\text { The existence of fairs relating to music, instruments and } \\
\text { galleries }\end{array}$ & 1.07 \\
\hline 12 & $\begin{array}{l}\text { Easy access to music center and its proximity to main } \\
\text { highway, given the traffic condition }\end{array}$ & 1.15 \\
\hline 13 & $\begin{array}{c}\text { The existence of a friendly space with architectural } \\
\text { elements for easing interaction and creating the sense of } \\
\text { happiness }\end{array}$ & 1.02 \\
\hline 14 & $\begin{array}{l}\text { Aesthetics in the form of buildings by combination of } \\
\text { architecture and music in the building }\end{array}$ & 1.17 \\
\hline 15 & $\begin{array}{l}\text { Creating opportunities to enjoy music in all seasons (semi- } \\
\text { open spaces design etc.). }\end{array}$ & 1.11 \\
\hline
\end{tabular}

Source: author, 2016

Table 4 and 5 demonstrate chronbach coefficient alpha in each section of the questionnaire. According to these tables, all items have acceptable reliability (above 0.7 ).

\section{Evaluation of the research main hypothesis}

H0 - Individual and social factors don't have similar roles as qualitative factors in designing music centers.

H1- Individual and social factors have similar roles as qualitative factors in designing music centers.

Table 6 "Results of Binominal test for the comparison of frequency of responses less than average with responses in average and above average, regarding music centers

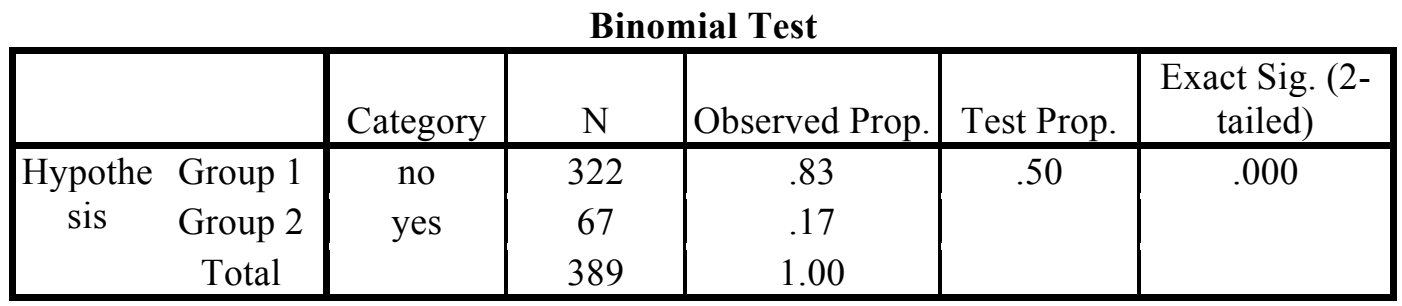

Source: author, 2016

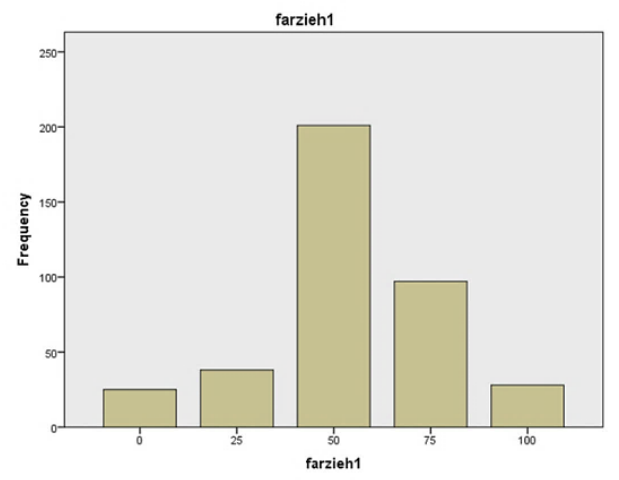

Fig 2. The chart of major hypothesis, source: author,2016

Results of table 2 show that the frequency of responses more than average was 389(83\%). Given the fact that $\mathrm{P}$ value is less than 0.05 , the frequency difference in 2 groups turned out to be significant at 
$99 \%$. Therefore, $\mathrm{H} 0$ is Individual and social factors don't have similar roles as qualitative factors in designing music centers.

\section{The evaluation of research data using Pearson Correlation Coefficient}

Evaluation was conducted using Pearson Correlation Coefficient. Pearson Correlation Coefficient is a measurement in which correlation between two or more variables is studied. In this research, researcher aims to know if a change in a variable can cause a change in other variables, and if so, how and to what extent. Finally variables were ranked using Friedman test.

Table 7 Ranking of individual and social factors affecting the extent to which people visit music centers

\begin{tabular}{|c|c|c|c|c|c|}
\hline Row & $\begin{array}{c}\text { Individual and social } \\
\text { factors affecting the extent } \\
\text { to which people welcome } \\
\text { the space }\end{array}$ & $\begin{array}{c}\text { Significance } \\
\text { level }\end{array}$ & $\begin{array}{c}\text { Pearson } \\
\text { Correlation } \\
\text { coefficient } \\
\text { rate } \\
\end{array}$ & Number & Accepted/Rejected \\
\hline 1 & $\begin{array}{l}\text { The effect of users' individual } \\
\text { characteristics (age, } \\
\text { education level, gender etc) }\end{array}$ & 0.4 & 0.00 & 389 & Accepted \\
\hline 2 & $\begin{array}{l}\text { The effect of economic status } \\
\text { (people's income level) on the } \\
\text { extent to which students } \\
\text { welcome music and people } \\
\text { attend concerts }\end{array}$ & 0.35 & 0.05 & 389 & Accepted \\
\hline 3 & $\begin{array}{l}\text { Users' sociocultural } \\
\text { conditions (the effect of } \\
\text { religious and popular } \\
\text { beliefs... }\end{array}$ & 0.24 & 0.03 & 389 & Accepted \\
\hline 4 & $\begin{array}{l}\text { Satisfying citizens' spiritual } \\
\text { needs and providing their } \\
\text { psychological comfort ( } \\
\text { especially youths) when } \\
\text { attending concerts and music } \\
\text { centers }\end{array}$ & 0.65 & 0.05 & 389 & Accepted \\
\hline 5 & $\begin{array}{l}\text { The effect of the sense of } \\
\text { peace experienced by people } \\
\text { listening to music in their } \\
\text { leisure time. }\end{array}$ & 0.34 & 0.00 & 389 & Accepted \\
\hline 6 & $\begin{array}{l}\text { The effect of religious } \\
\text { constraints on playing and } \\
\text { listening to music or } \\
\text { performing a concert ( music } \\
\text { from and ideological } \\
\text { viewpoint) }\end{array}$ & 0.26 & 0.06 & 389 & Accepted \\
\hline 7 & $\begin{array}{c}\text { Evaluation of people's } \\
\text { tendency (especially youths) } \\
\text { to attend concerts }\end{array}$ & 0.62 & 0.00 & 389 & Accepted \\
\hline
\end{tabular}

Source: author,2016

Table 8 Ranking of qualitative factors affecting the extent to which people visit music centers

\begin{tabular}{|c|c|c|c|c|c|}
\hline Row & $\begin{array}{c}\text { factors affecting the extent } \\
\text { to which people welcome }\end{array}$ & $\begin{array}{c}\text { Significance } \\
\text { level }\end{array}$ & $\begin{array}{c}\text { Pearson } \\
\text { Correlation }\end{array}$ & Number & Accepted/Rejected \\
\hline
\end{tabular}




\begin{tabular}{|c|c|c|c|c|c|}
\hline & the space & & $\begin{array}{c}\text { coefficient } \\
\text { rate }\end{array}$ & & \\
\hline 1 & $\begin{array}{l}\text { The effect of colors used in } \\
\text { the design of music centers ( } \\
\text { inside and outside the } \\
\text { building such as using happy } \\
\text { and energetic colors }\end{array}$ & 0.38 & 0.00 & 389 & Accepted \\
\hline 2 & $\begin{array}{c}\text { Adding dynamism and } \\
\text { attraction to the space by } \\
\text { good lighting and music at } \\
\text { night in order to attract more } \\
\text { visitors }\end{array}$ & 0.62 & 0.00 & 389 & Accepted \\
\hline 3 & $\begin{array}{l}\text { Creating visual attractions } \\
\text { and appropriate viwes such } \\
\text { as green space and fountain } \\
\text { as well as playground for } \\
\text { children }\end{array}$ & 0.27 & 0.03 & 389 & Accepted \\
\hline 4 & $\begin{array}{c}\text { Availability of outdoor } \\
\text { spaces for holding concerts } \\
\text {,ceremonies (harvest), } \\
\text { traditional dancing, religious } \\
\text { ceremonies (Tazieh -Passion } \\
\text { Play) and street } \\
\text { performances }\end{array}$ & 0.75 & 0.04 & 389 & Accepted \\
\hline 5 & $\begin{array}{l}\text { Availability of commercial } \\
\text { spaces (selling music-related } \\
\text { stuff such as poster, CD and } \\
\text { different instruments etc.). }\end{array}$ & 0.23 & 0.03 & 389 & Accepted \\
\hline 6 & $\begin{array}{c}\text { Providing people's } \\
\text { psychological security in } \\
\text { such populous spaces as } \\
\text { music centers. }\end{array}$ & 0.87 & 0,01 & 389 & Accepted \\
\hline 7 & $\begin{array}{l}\text { Adding variety to the space } \\
\text { by running coffee shops, } \\
\text { restaurants and communal } \\
\text { spaces for having interaction } \\
\text { in order to attract all groups. }\end{array}$ & 0.45 & 0.00 & 389 & Accepted \\
\hline 8 & $\begin{array}{l}\text { Separating children's pace } \\
\text { from adults' along with } \\
\text { keeping relationship in } \\
\text { music centers }\end{array}$ & 0.76 & 0.00 & 389 & Accepted \\
\hline 9 & $\begin{array}{l}\text { Inviting great music teachers } \\
\text { and masters to make music } \\
\text { centers more successful ( to } \\
\text { perform music, give lecture } \\
\text { and teach etc.) }\end{array}$ & 0.87 & 0.00 & 389 & Accepted \\
\hline 10 & $\begin{array}{l}\text { Including inexpensive spaces } \\
\text { for music practice in music } \\
\text { centers }\end{array}$ & 0.23 & 0.02 & 389 & Accepted \\
\hline 11 & $\begin{array}{l}\text { The existence of fairs } \\
\text { relating to music, } \\
\text { instruments and galleries }\end{array}$ & 0.56 & 0.00 & 389 & Accepted \\
\hline 12 & $\begin{array}{l}\text { Easy access to music center } \\
\text { and its proximity to main }\end{array}$ & 0.23 & 0.02 & 389 & Accepted \\
\hline
\end{tabular}




\begin{tabular}{|c|c|c|c|c|c|}
\hline & $\begin{array}{c}\text { highway, given the traffic } \\
\text { condition }\end{array}$ & 0.65 & 0.05 & 389 & Accepted \\
\hline 13 & $\begin{array}{c}\text { The existence of a friendly } \\
\text { space with architectural } \\
\text { elements for easing } \\
\text { interaction and creating the } \\
\text { sense of happiness }\end{array}$ & 0.42 & 0.00 & 389 & Accepted \\
\hline 14 & $\begin{array}{c}\text { Aesthetics in the form of } \\
\text { buildings by combination of } \\
\text { architecture and music in the } \\
\text { building }\end{array}$ \\
\hline $\begin{array}{c}\text { Creating opportunities to } \\
\text { enjoy music in all seasons } \\
\text { (semi-open spaces design } \\
\text { etc.). }\end{array}$ & 0.37 & 0.00 & 389 & Accepted \\
\hline
\end{tabular}

Source; author, 2016

\section{Frequency distribution and the percentage of responses made by samples}

In the survey conducted on the factors affecting the extent to which people welcome a music center, qualitative and individual/social factors were tested separately and percentage frequency of responses made by samples were investigated and then ranked using Friedman Test.

Table 9 percentage frequency and ranking factors affecting the extent to which people welcome a music center

\begin{tabular}{|c|c|c|c|c|c|c|c|c|}
\hline & $\begin{array}{c}\text { response items } \\
\text { nking affecting the exten } \\
\text { people } \\
\text { welcome a music cente }\end{array}$ & to which & 0 & $25 \%$ & $50 \%$ & $75 \%$ & $100 \%$ & Ranking \\
\hline 1 & The effect of users' individual & Number & 38 & 50 & 97 & 139 & 65 & 3.33 \\
\hline & $\begin{array}{l}\text { characteristics (age, education } \\
\text { level, gender etc) }\end{array}$ & Percentage & 9.8 & 12.9 & 24.9 & 35.7 & 16.7 & \\
\hline 2 & The effect of economic status & Number & 8 & 43 & 88 & 128 & 122 & 4.07 \\
\hline & $\begin{array}{c}\text { extent to which students } \\
\text { welcome music and people } \\
\text { attend concerts }\end{array}$ & Percentage & 2.1 & 11.1 & 22.6 & 32.9 & 31.4 & \\
\hline 3 & Users' sociocultural conditions & Number & 10 & 64 & 124 & 133 & 58 & 3.47 \\
\hline & $\begin{array}{c}\text { (the effect of religious and } \\
\text { popular beliefs... }\end{array}$ & Percentage & 2.6 & 16.5 & 31.9 & 34.2 & 14.9 & \\
\hline 4 & $\begin{array}{l}\text { Satisfying citizens' spiritual } \\
\text { needs and providing their }\end{array}$ & Number & 8 & 39 & 62 & 126 & 154 & 4.63 \\
\hline & $\begin{array}{l}\text { psychological comfort ( } \\
\text { especially youths) when } \\
\text { attending concerts and music } \\
\text { centers }\end{array}$ & Percentage & 2.1 & 10.0 & 15.9 & 32.4 & 39.6 & \\
\hline 5 & The effect of the sense of peace & Number & 6 & 16 & 66 & 125 & 176 & 4.67 \\
\hline & $\begin{array}{c}\text { experienced by people } \\
\text { listening to music in their } \\
\text { leisure time. }\end{array}$ & Percentage & 1.5 & 4.1 & 17.0 & 32.1 & 45.2 & \\
\hline 6 & The effect of religious & Number & 12 & 51 & 116 & 128 & 82 & 3.63 \\
\hline
\end{tabular}




\begin{tabular}{|c|c|c|c|c|c|c|c|c|}
\hline & $\begin{array}{c}\text { constraints on playing and } \\
\text { listening to music or } \\
\text { performing a concert (music } \\
\text { from and ideological } \\
\text { viewpoint) }\end{array}$ & Percentage & 3.1 & 13.1 & 29.8 & 32.9 & 21.1 & \\
\hline 7 & $\begin{array}{c}\text { Evaluation of people's tendency } \\
\text { (especially youths) to attend } \\
\text { concerts }\end{array}$ & Number & 8 & 20 & 81 & 161 & 119 & 4.21 \\
\cline { 2 - 10 } & Percentage & 2.1 & 5.1 & 20.8 & 41.4 & 30.6 & \\
\hline
\end{tabular}

Source: author, 2016

Table 10 Percentage frequency and ranking factors affecting the extent to which people welcome the space

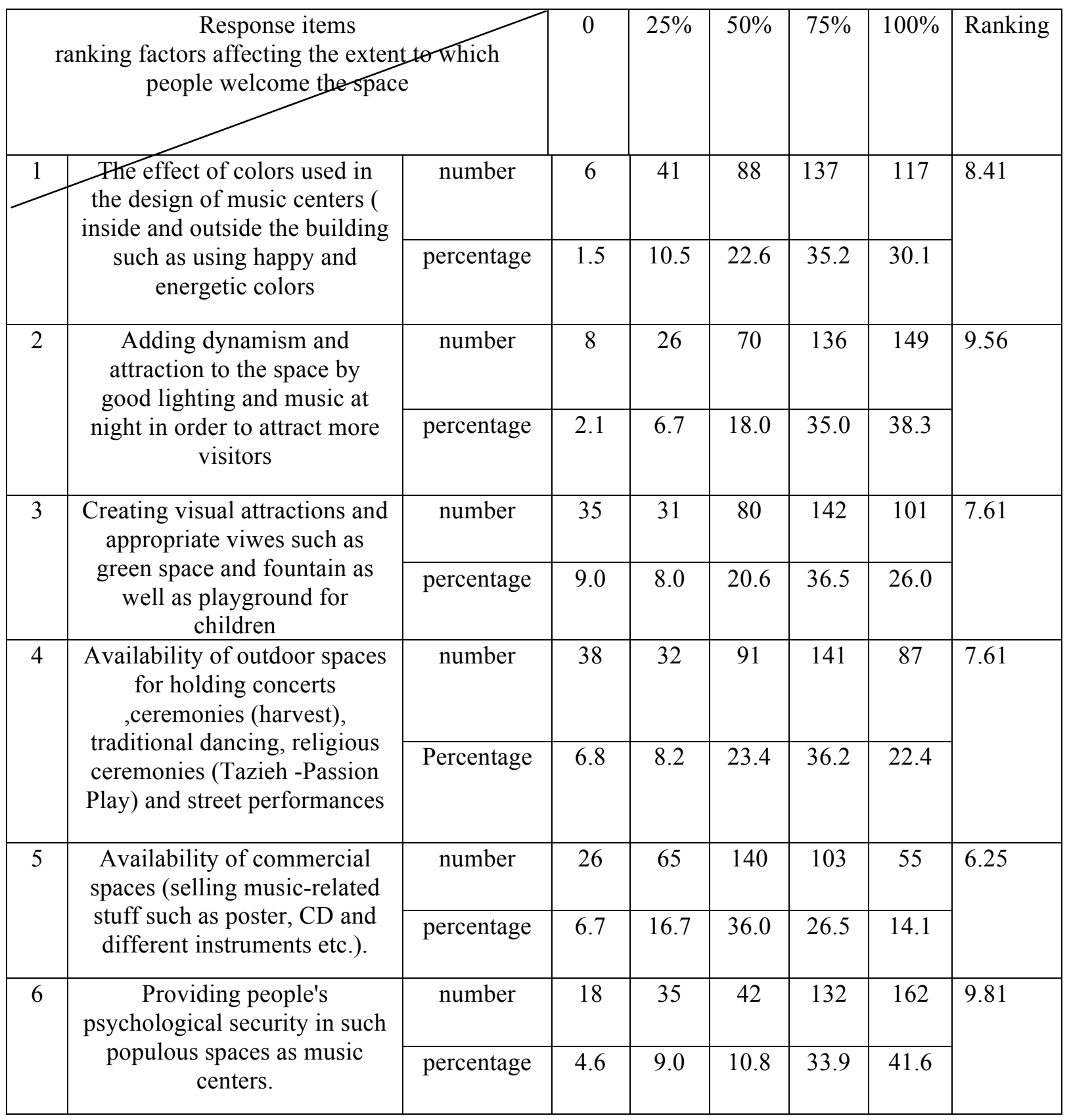




\begin{tabular}{|c|c|c|c|c|c|c|c|c|}
\hline \multirow[t]{2}{*}{7} & \multirow{2}{*}{$\begin{array}{l}\text { Adding variety to the space by } \\
\text { running coffee shops, } \\
\text { restaurants and communal } \\
\text { spaces for having interaction } \\
\text { in order to attract all groups. }\end{array}$} & number & 16 & 48 & 106 & 106 & 113 & \multirow[t]{2}{*}{8.02} \\
\hline & & percentage & 4.1 & 12.3 & 27.2 & 27.2 & 29.0 & \\
\hline \multirow[t]{2}{*}{8} & \multirow{2}{*}{$\begin{array}{l}\text { Separating children's pace } \\
\text { from adults' along with } \\
\text { keeping relationship in music } \\
\text { centers }\end{array}$} & number & 21 & 33 & 78 & 148 & 109 & \multirow[t]{2}{*}{8.51} \\
\hline & & percentage & 5.4 & 8.5 & 20.1 & 38.0 & 28.0 & \\
\hline \multirow[t]{3}{*}{9} & \multirow{3}{*}{$\begin{array}{l}\text { Inviting great music teachers } \\
\text { and masters to make music } \\
\text { centers more successful ( to } \\
\text { perform music, give lecture } \\
\text { and teach etc.) }\end{array}$} & number & 20 & 45 & 45 & 127 & 152 & \multirow[t]{3}{*}{9.57} \\
\hline & & & & & & & & \\
\hline & & percentage & 5.1 & 11.6 & 11.6 & 32.6 & 39.1 & \\
\hline \multirow[t]{2}{*}{10} & \multirow{2}{*}{$\begin{array}{l}\text { Including inexpensive spaces } \\
\text { for music practice in music } \\
\text { centers }\end{array}$} & number & 14 & 21 & 71 & 110 & 173 & \multirow[t]{2}{*}{9.61} \\
\hline & & & 3.6 & 5.4 & 18.3 & 28.3 & 44.5 & \\
\hline \multirow[t]{2}{*}{11} & \multirow{2}{*}{$\begin{array}{c}\text { The existence of fairs relating } \\
\text { to music, instruments and } \\
\text { galleries }\end{array}$} & number & 10 & 46 & 91 & 144 & 98 & \multirow[t]{2}{*}{8.31} \\
\hline & & percentage & 2.6 & 11.8 & 23.4 & 37.0 & 25.2 & \\
\hline \multirow[t]{2}{*}{12} & \multirow{2}{*}{$\begin{array}{l}\text { Easy access to music center } \\
\text { and its proximity to main } \\
\text { highway, given the traffic } \\
\text { condition }\end{array}$} & number & 29 & 37 & 103 & 120 & 100 & \multirow[t]{2}{*}{7.76} \\
\hline & & percentage & 7.5 & 9.5 & 26.5 & 30.8 & 25.7 & \\
\hline \multirow[t]{3}{*}{13} & \multirow{3}{*}{$\begin{array}{l}\text { The existence of a friendly } \\
\text { space with architectural } \\
\text { elements for easing interaction } \\
\text { and creating the sense of } \\
\text { happiness }\end{array}$} & number & 12 & 33 & 85 & 155 & 104 & \multirow[t]{3}{*}{8.18} \\
\hline & & & & & & & & \\
\hline & & percentage & 3.1 & 8.5 & 21.9 & 39.8 & 26.7 & \\
\hline \multirow[t]{2}{*}{14} & \multirow{2}{*}{$\begin{array}{l}\text { Aesthetics in the form of } \\
\text { buildings by combination of } \\
\text { architecture and music in the } \\
\text { building }\end{array}$} & number & 20 & 59 & 53 & 147 & 110 & \multirow[t]{2}{*}{9.71} \\
\hline & & percentage & 5.1 & 15.2 & 13.6 & 37.8 & 28.3 & \\
\hline \multirow[t]{2}{*}{15} & \multirow{2}{*}{$\begin{array}{l}\text { Creating opportunities to } \\
\text { enjoy music in all seasons } \\
\text { (semi-open spaces design } \\
\text { etc.). }\end{array}$} & number & 18 & 28 & 50 & 124 & 169 & \multirow[t]{2}{*}{8.51} \\
\hline & & percentage & 4.6 & 7.2 & 12.9 & 31.9 & 43.4 & \\
\hline
\end{tabular}

Source: author, 2016

\section{RESULTS}

Results from data indicate that from 389 cases selected as statistical population, $48.3 \%$ were men and $51.7 \%$ were women which show an approximate balance between genders. The items respondents referred to in their responses can be listed hierarchically as: Aesthetics in the form of buildings by combination of architecture and music in the building; Proving people with psychological security in populous areas such as music centers; creating dynamism and attraction by good lighting and music at night; including inexpensive spaces for music practice in music centers; Inviting great music teachers and masters to make music centers more successful, and using happy and energetic colors in the design music centers. Additionally, results demonstrate that qualitative factors are of higher importance compared to individual/social factors and this emphasizes the necessity of considering appropriate design of music centers in country. Although it is visible that people attend outdoor live music concerts, it cannot be proof of public welcoming and people's satisfaction with such spaces. 
However, despite the insufficient spaces required in country interest to music can motivate people to attend such places. Given the research findings, following are suggested:

1. According to modern life and change in people's lifestyle, creating visual attractions such as using appropriate lighting during night hours in open and semi-open spaces of music centers we can make social groups have better interactions.

2. Creating multifunctional spaces in music centers and giving attention to various activities (an opportunity for all people to use the space in group) and also combining the building with the outer space and holding a special ceremony in it, we can build a positive and memorable image in people's mind.

3. Due to gorgeous styles formed inside and outside the building and also circulation design with upward flow, combining music and architecture can make the music center be dynamic and attractive.

4. Attention to individual and group security in populous spaces like music center can add a sense of peace to the space and this, itself, reduce psychological tension at the time of performance in music center.

5. Using architectural elements can make the music center like a friendly space where interaction occurs and this can increase people's satisfaction and will be an appropriate place for everyone.

\section{REFERENCES}

Aqa Ahmadi, QorbanAli, Qolizdeh, Z, Mirmohammadi, F., (2013), "The relationship between socioeconomic status and use of music in the youths of metropolis of Tehran", Journal of Sociological Studies of Youth, Issue XI, pp. 9-28

Iman, Muhammad Taqi, Zanjry, N., Nasibeh EskandariPur, Ebrahim, (2010) "exploring the Music consumers' subjective meaning system ", Journal of Cultural Studies, No. 4, pp. 85-112.

Rezai Nia, A. (2003), "the ancient religious music in Iran", Fine Arts Magazine, No. 13, Tehran University Press, pp. 106-117.

Rizvi Toosi, Syed Mujtaba, Yahk, Sajad. (2014), "musical consumption (A Study on the trend of music in society)", Journal of Cultural Studies and Communications, Issue 25, pp. 7-36

Stari Sarbanqoli, Hassan, Shahed, Mahlaqa (2012), "Similarities between Iranian musical concepts and architecture of Iranian gardens (Case Study: Fin Garden in Kashan), Journal of Architecture and Urban Utopia, No. 5, pp. 91-110

Sohangir, Sarah, Nowruz Borazjani, Vida, (2012), "Comparative Study of the conceptual link between music space and architecture (in the pre-modern period and then in the West)", Journal of Baq-e- Nazar, No. 23, pp. 33-46.

Samim, Reza Ghasemi, Vahid. (2009), "tendency to consume popular music and level of aggression among students; case study: Isfahan University students", Journal of Cultural Studies, Volume II, Issue 8, pp. 243-262.

Fazeli, Mohamad., (2005), "the sociology of music consumption", Journal of Cultural Studies and Communication, pp. 27-53

Ghasemi, Zahra, Amo Quli Mirakhondi, Marzieh., (2012), "Factors affecting youths' tendency to music (Case study: Youths aged 17 to 27 of Regions 1 and 3 in Tehran, Iran)", Journal of socialogy studies in Iran, Issue 4, pp. 61-78

Ghasemi, Vahid, Samim, Reza. (2008) "study on the relationship between social stratification and cultural consumption using data on the use of music in Tehran," Iranian Journal of Sociology, No. 1 and 2, pp. 80-101

Motahari Elhami, Mojtaba, (2003), "the article of arts, mysticism and music music", Journal of Fine Arts, Issue 15, pp 82.96

Mehdi Nejad, Mohammad J., (2004), "Grammar of leading music (An investigation of the relationship between spiritual music, Iranian culture and Islamic mysticism)", Fine Arts, Issue 17, pp. 87-96

Vdadhir, Abu Ali, Aminian, Ehsan, Tabatabai, Asiyeh al-Sadat, Salmani, Mohammad. J, (2011), 
"Youth and pop (An investigation of social factors associated with a Tarbiate Molam students' tendency to pop the)", Iran social issues, No.1, summer, pp. $167-193$

Azizi, Mohammad Mehdi, Malek Nejad, Sarem, (2007), "A comparative study of two residential complex pattern (normal and high)", Journal of Fine Arts, Issue 32.

EiniFar, Ali.R, (2000), " Human- environmental factors - affecting the design of residential complexes", Fine Arts Magazine, No. 8, pp. 109-118.

Kashfi, Mohammad Ali, Hosseini, Seyed Baqer, Noroozian Maleki, Saeed. (2012), "The role of public spaces, and residential high-rise buildings in enhancing social interactions; (Case study: Tehran International Tower)", Journal of Urban Management, Issue 30, pp. 7 -18.

Sarmast, Bahram, Motavaseli, Mohammad.M (2010), "Analysis of the role of urban scale in the sense of place", Journal of Urban Management, No. 26.

Yazdanfar, Sayyed Abbas Hosseini, Sayyed Baqer, Zarodi, Mostafa, (2013), "Public spaces and social interactions enhancement. Case study: Kosar residential complex and the $2^{\text {nd }}$ phase of Ekbatan residential complexes ", Journal of Urban Management, Issue 32, pp. 7-22 .

Hafeznia, Mohammad Reza, 2009, An introduction to Research Methodology in Human Sciences, Sixteenth Edition, Tehran, SAMT publication.

Rafieian, Mojtaba and Khodaie, Zahra., (2009), Evaluation of indicators and Criteria of satisfaction of the citizens of urban public spaces, Strategy Magazine, Issue 53

Barendregt, B , (2006), " The art of no-seduction: Muslim boy-band music in Southeast Asia and the fear of the female voice".

Bennett, A , (2000) , " Popular music and youth culture: music, identity and place". Macmillan Press Ltd.

Cook, N, (2000), " Analysing musical multimedia".

Cook, N. (1990). " Music, imagination, and culture". Clarendon Press/Oxford University Press 265

pp.

Davies, S, (2001), " Musical works and performances: A philosophical exploration".

De nore, tia (2004) " music in everyday life", Cambridge : Cambridge university press .

Douglas,mike, (2003), " urban space in globalization era". Environment and Behaviour, 33(1), pp 54-77.

Gabrielsson, A, (2001), " Emotions in strong experiences with music Series in affective science ", (pp. 431-449). New York, NY, US: Oxford University Press, viii, 487 pp.

Hajer, M. \& Reijndorp, A. (2001) " In Search of New Public Domain". Rotterdam: NAI Publishers . Huang, S.-C. L. (2006), " A study of outdoor interactional space in high-rise housing", Landscape and Urban Planning 78 (3), pp 193-204.

Juslin, P. N, \& Sloboda, J. A , (2001), " Music and emotion: Theory and research". Oxford University Press. pp 487.

Juslin, P. N., \& Laukka, P. (2003), " Communication of emotions in vocal expression and music performance: Different channels, same code? ", Psychological bulletin, 129(5), pp 770.

Kivy, Peter, (2002), " Introduction to a Philosophy of Music".

Lewisohn, L, (1997), " The sacred music of Islam: Samā'in the Persian Sufi tradition", British

Journal of Ethnomusicology, 6(1), pp 1-33.

Mahdavinejad, M.J, (2004), "Syntax of Avant-gard Music" , Journal of Fine Arts, pp , 17, 87- 96

Maconie, R. (1990). " The concept of music"

Otterbeck, J, (2008), " Battling over the public sphere: Islamic reactions to the music of today", Contemporary Islam, 2(3), pp 211-228.

Robinson, J, (2007), " Deeper than reason: Emotion and its role in literature, music, and art".

Sloboda, J. A, \& Juslin, P. N , (2001), " Psychological perspectives on music and emotion) " .pp. 71104 Oxford University Press, viii, 487 pp.

Storr, A, (1992)," Music and the mind ", Free Press.

Sennett, Richard.( 1974). "The Fall of Public Man": New York, W W Norton \& Company.

Xenakis , I , (2008), " Music and Architecture", New York : Pendragon University Press. 